\title{
Distinção Parlamentar - Perfis Singulares da Política Brasileira
}

\author{
Prof ${ }^{a}$. Dra. Andréa M. de Freitas, Simone Boró*
}

\section{Resumo}

Esta pesquisa investiga os perfis socioeconômicos e de parentesco dos parlamentares eleitos no pleito de 2014 de cinco Assembleias Legislativas Estaduais - Assembleia Legislativa do Estado do Amazonas (ALEAM), Assembleia Legislativa do Estado do Espírito Santo (ALES), Câmara Legislativa do Distrito Federal (CLDF), Assembleia Legislativa do Estado de Pernambuco (ALEPE) e Assembleia Legislativa do Estado do Paraná (ALEP) - a fim de delinear condicionantes dos perfis típicos de acesso a estes cargos eletivos.

Palavras-chave: Paridade de gênero, capitais políticos, perfis singulares.

\section{Introdução}

A mobilização acentuada de diferentes tipos de capitais pelos grupos dominantes na esfera política nacional contribui para a perpetuação de sua posição hierarquizada de poder, asseverando a marginalidade do gênero feminino dentro do jogo político institucional. A expressão dessa mobilização desigual dos capitais políticos pode ser visibilizada nos meios de acesso dos indivíduos à esfera política institucional. Sob este escopo, categorizam-se quatro dimensões de capitais mais relevantes e frequentemente mobilizados pelos candidatos para a construção dos perfis singulares de acesso aos cargos eletivos: (1) capital econômico concentração elevada de patrimônio e renda; (2) capital midiático - vínculo com os meios de comunicação; (3) capital familiar - grau de parentesco com algum outro político da mesma família; e (4) capital institucional trajetória política formada dentro dos partidos políticos ou pelo exercício de outros mandatos eletivos. Esta análise das dimensões do capital político permite construir perfis típicos que acessam o espaço político institucional brasileiro, inibindo o êxito de perfis destoantes.

\section{Resultados e Discussão}

A criação do banco de dados com informações referentes a 181 deputados estaduais e distritais eleitos em 2014, no conjunto das cinco Assembleias Legislativas Estaduais - ALEAM, ALES, CLDF, ALEPE e ALEP -, permite verificar a porcentagem diminuta de mulheres nas cadeiras de deputados estaduais e distritais, representando apenas $11 \%$ dos parlamentares, como reflexo de uma baixa capacidade de mobilização de capital político por estas candidaturas e pela composição de um perfil típico de atuação nesta esfera. O estudo demonstra maior capacidade de mobilização de capital político pelos homens, que em $17 \%$ dos casos concentram três ou mais tipos de capitais e em apenas $37 \%$ dos casos apresentam como esteio para a política uma única forma de capital, em oposição, respectivamente, ao índice de $5 \%$ com mais de três capitais e de $65 \%$ com apenas um capital entre as mulheres eleitas. Ademais, identifica-se que $45 \%$ das deputadas eleitas manifestam um vínculo familiar com algum parente político em cargo de liderança, marcandose como característica dependente para o esteio destas candidaturas e para sua eficaz atuação no campo político. Em oposição, registra-se apenas $5 \%$ de deputadas estaduais com significativo capital econômico.
Figura 1. Distribuição de capitais nos parlamentares analisados

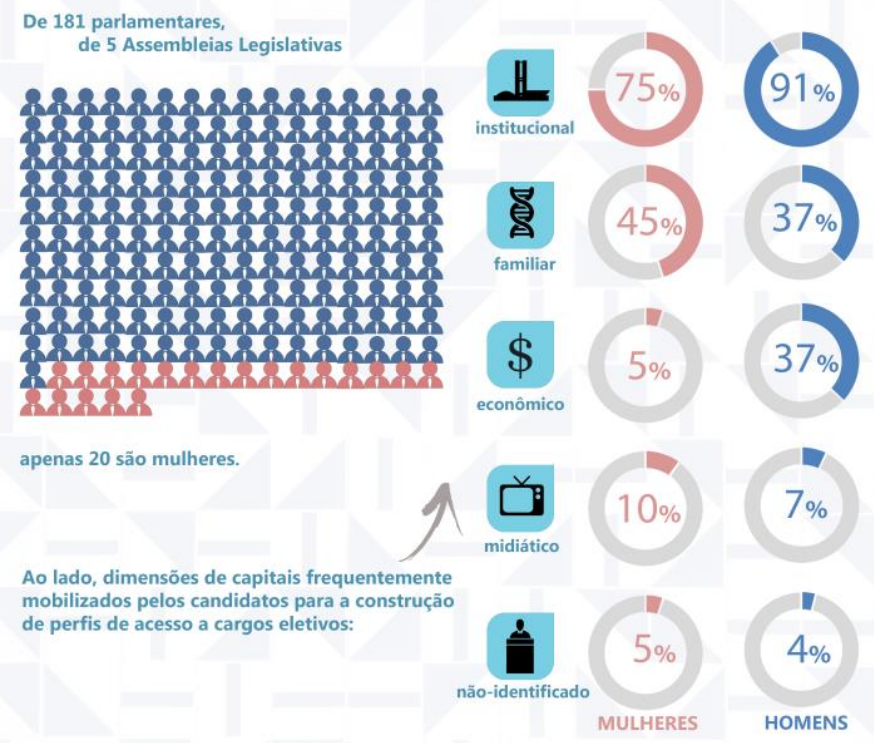

\section{Conclusões}

Apesar dos avanços legais para a ampliação do coeficiente de mulheres na esfera política, o elemento impeditivo para sua plena efetivação - sobretudo, no funcionamento da Lei oㅜ 9.504/1997 - residiria em uma objeção imposta pelo jogo político brasileiro, caracterizado por uma composição limitada dos perfis capazes de obterem êxito nos pleitos eleitorais. Essa restrição reside no fato de que as candidaturas masculinas tendem a ser mais exitosas por conseguirem mobilizar variadas fontes de recursos, sejam elas provenientes de capital econômico, político, midiático, ou de capital familiar, tornando-se candidaturas mais viáveis. Em oposição, as candidaturas femininas, por não incorporarem uma pluralidade de capitais, encontram no capital familiar um esteio para o acesso à esfera política.

\section{Agradecimentos}

Agradece-se a todos que contribuíram, direta $e$ indiretamente, para a realização desta pesquisa, em especial, ao fomento prestado pelo CNPq e a orientação da Profá. Dra. Andréa Marcondes de Freitas.

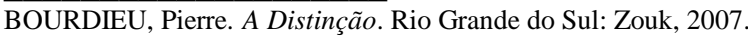

MIGUEL, Luís Felipe et al. Capital Familiar e Carreira Política no Brasil: Gênero, Partido e Região nas Trajetórias para a Câmara dos Deputados. Revista de Ciências Sociais. Rio de Janeiro, vol. 58, n 3, pp. 721-747, 2015. 